\title{
SLC6A4 wt Allele
}

National Cancer Institute

\section{Source}

National Cancer Institute. SLC6A4 wt Allele. NCI Thesaurus. Code C105875.

Human SLC6A4 wild-type allele is located in the vicinity of $17 q 11.2$ and is approximately $42 \mathrm{~kb}$ in length. This allele, which encodes sodium-dependent serotonin transporter protein, plays a role in serotonin uptake. Polymorphism in the promoter region affects gene expression and lower gene expression is associated with depression. Coding region variations are associated with genetic susceptibility to both obsessive-compulsive disorder and alcoholism. 